\title{
Influence of Leader-Member Exchange of Employees' Affective Commitment in Saudi Arabia Universities
}

\author{
Rajeh Bati Almasradi, Siti Aisyah Panatik, Nurul Farhana Noordin
}

\begin{abstract}
The emotional attachment employees' exhibit towards their workplaces, known as affective commitment, has a determining influence on the quality and sustainability of their performance. Employees with strong visceral attachment tend to record more successful careers. However, the quality of this emotional attachment is a function of the quality of interactions between the employees and their leaders. This study, therefore, examines the relationship between leader-member exchange (LMX) and affective commitment (AC) in a sample of 373 administrative employees drawn from Saudi Arabian higher educational institutions. The survey data were collected were analysed using a partial least squares approach to structural equation modelling. Outcomes of the analysis revealed that LMX positively and significantly affects $A C$. Also, the quality of the relationship between employees and their immediate managers is predicted by the level of employees' affective commitment.
\end{abstract}

Keywords : Leader-Member Exchange, Affective commitment, Saudi Arabia..

\section{INTRODUCTION}

The essence of leadership is the ability to influence others to willingly contribute to the realization of a common goal [1]. Therefore, the most significant function of leadership is affecting subordinate's behavior that also leads to exchange relationships between leaders and members. Leader-member exchange (LMX) refers to the high quality of interactions that takes place between purposive leaders and their well-led subordinates. LMX presupposes excellent understanding and symbiotic cooperation between and among leaders and their charges [2]. Indeed, research has established that the subordinates tend to nurse high loyalty for their organizations, show higher levels of satisfaction with their jobs, perform excellently, exhibit low-stress symptoms, and hardly nurse intentions to quit the organizations where the LMX is higher [3-5]. Increase in affective commitment will increase the performance in the job as well as increasing the productivity [6]. Affective commitment is a significant attitude toward

Revised Manuscript Received on October15, 2019

* Correspondence Author

Rajeh Bati Almasradi*, Azman Hashi International Business School,Universti Teknologi Malaysia, Johor, Malaysia.

Email: rajehphd89@gmail.com

Siti Aisyah Panatik, School of Human Resource Development, Faculty of Social Sciences and Humanities, Universti Teknologi Malaysia, Johor, Malaysia. Email: saisyah@utm.my

Nurul Farhana Noordin, School of Human Resource Development, Faculty of Social Sciences and Humanities, Universti Teknologi Malaysia, Johor, Malaysia. Email: nrfarhana@utm.my

employee's citizenship behavior in the organization due to the emotional attachment of employees.

Also, the literature on LMX shows an extensive empirical study has been conducted to examine the effects of leader-member exchange [7-9]. However, most research has yet examined multiple facets of LMX in one study. Therefore, research that investigates the diverse impacts of LMX facets is still needed due to the lack of investigations in this matter [10]. LMX consists of four dimensions or facets: the emotional element (affect), the commitment facet (contribution), and the professional respect dimension. The integration of the LMX dimensions as the predictor variables in this study captu4res a broader range of social context in the working environment. The LMX dimensions cover the interactions and relationships between leaders and their subordinates [11]. Previously, the LMX dimensions were studied separately in most research. In research by Ibrahim, Ghani and Amin [12], some of the LMX dimensions are found to very significant and positive compared to some other dimensions. Therefore, this study examines the influences of the four LMX facets (affect, loyalty, contribution, and professional respect) on the affective commitment of administrative employees selected from Saudi Arabian universities.

\section{A. Leader-Member Exchange (LMX)}

The potency or otherwise of the chain linking leaders and subordinates in the organisation depends to a large extent on the cordiality of the numerous interactions that take place between them. Therefore, researchers see LMX as a concept built on several underlying facets that define the types of interactions between leaders, and the led [13]. For example, Dienesch and Liden [14] extracted three factors for the LMX concept to include affective component, loyalty element and contribution dimension. Moreover, along the same lines, professional respect was suggested by Liden and Maslyn [11] as the fourth dimension of LMX. Therefore, these dimensions have been used as the constituent factors for assessing the quality of LMX in workplaces. Graen and Uhl-Bien [15] and Babič [16] have severally demonstrated that the LMX construct was built on the tripod of respect among leaders and followers as well as feelings of trust and appreciation of obligations.

This study, therefore, subscribes to the Liden and Maslyn [11] conceptualization of LMX as a multidimensional construct. Liden and Maslyn [11], supported by Jing-zhou and Wen-Xia [18], set the structure and meaning of the LMX construct and its four dimensions. 
Affect is the mechanism by which a leader and his or her subordinate are linked together in trust and mutual understanding. This mutual understanding has its basis in the attraction each member of the leader-subordinate dyad nurses for each other and do not include mutual respect arising out of professional competencies of each of the duo $[11,18]$. Loyalty is reciprocal. It describes the open mutual support both leaders and followers render to each other in the course of doing their collective responsibilities and includes standing for each other's goals and visions in the course of organizational life $[11,18]$. Contribution describes what value each person in the leader-member dyad brings to the table in pursuit of goals and vision $[11,18]$. Finally, professional respect describes the global name or reputation for professional excellence each member of the leader-subordinate dyad has built for themselves [11,18].

\section{B. Affective Commitment}

Research has shown that affective commitment benefits organizations by attenuating their staff turnover cost and the adverse consequences associated with recurring changes that mark the life of organizations. All these benefits stem from employees' show of strong belief and attachment to organizations and their respective goals and value systems [19]. The overall collective value system of the organization and the overarching macro-economic realities of the moment have been identified as the two general perspectives from which affective commitment in organizations could be considered [20]. Researchers have consistently reported that the commitment of employees to the goals and objectives of organizations represent the most reliable stabilizing mechanism for consistent employee behavior. Thus, it holds the promise of positively impacting organizational performance and worker well-being [21]. When an employee matches his efforts with the goals of his workplace, commitment results inevitably [22].

Three elements define organizational commitment: namely, a strong belief in and acceptance of organizational objectives, a quest for more effort towards realizing organizational objectives, and a strong need to stay with the organization over time. These three elements form the basis or the three approaches to understanding organizational commitment. The three approaches to commitment are labelled 'effective', 'continuance' and 'normative' commitment [23]. A committed employee exhibits strong attachment to an organization and is willing to identify himself or herself with the objectives of the organization. Such an employee also is found to be continually involved in the work of the organization. A committed employee therefore hardly entertains leaving the organization and exhibits the least desire to do so. Continuance commitment, on the other hand, defines the cost and benefits of maintaining or severing membership of the organization. When it cost an employee too much to sever working relationships with the organization, they tend to stay put. Finally, normative commitment arises from the feeling of being obliged to continue working for an organization, perhaps in consideration of benefits the organization has conferred on the employee in the past [24].

Research has shown a positive affective commitment-absenteeism relationship. The committed worker always reports to work, and less committed ones record high levels of absenteeism. Also, highly committed employees are more hardworking and diligent, exhibit more prosaically and citizenship behaviors than their less committed counterparts. Employees with a high level of organizational commitment are seen to help colleagues with their work quickly, volunteer for extra tasks, participate in organizational activities, and give their voice (suggestions) on matters of the organisation. Committed employees seldom stay aloof of organizational activities and never neglect their duties but always remain loyal [23]. However, organizational commitment happens mostly where there is harmony between the employee's values and objectives and those of the organisation. Such value and goal congruence facilitate loyalty on the part of the employee who places a premium on his or her continued membership of the organisation [24-26].

Therefore, affective commitment is significant in this article as the outcome variable.

Hypothesis 1: LMX dimensions will significantly positively affect affective commitment.

H1a: Affect will significantly positively affect affective commitment.

H1b: Loyalty will significantly positively affect affective commitment

H1c: Contribution will significantly positively affect affective commitment.

H1d: Professional respect will significantly positively affect affective commitment.

\section{MATERIAL AND METHODS}

The survey method was employed in collecting data from a sample of 373 administrative employees selected from Saudi Arabian universities. The survey questionnaire elicited responses based on a 5-point Likert scale ranging from $1=$ strongly disagree to $5=$ strongly agree.

\section{A. LMX Measures}

Following the recommendation of Liden and Maslyn [11], the researchers measure LMX using the LMX-MDM scale because of the additional need to evaluate the role of instrumentality in a high-quality LMX context. Previous meta-analytic results upheld the sound psychometric properties of the LMX-MDM scale across research contexts. The survey instrument contains 12 questions, with four questions per dimension. Further, Liden and Maslyn [11] reported a .90 reliability index for the scale. The Cronbach $\alpha$ for the scale's dimensions are also acceptable: affect (.94), loyalty (.94), contribution (.85) and professional respect (.96) [11].

\section{B. Affective Commitment Measure}

Allen and Meyer [23] revealed that commitment has three aspects, which are affective commitment, continuance commitment, and normative commitment. Allen and Meyer's Affective Commitment Scale [23] will be used to measure affective commitment in this research. The concept of affective commitment corresponds closely to that of Porter et al.'s adaptation of the attitudinal organizational commitment [22]. The attitudinal organizational commitment is measured by the Organizational Commitment Questionnaire (OCQ) developed by Allen and Meyer [23]. The OCQ regards organizational commitment in terms of three interrelated 
dimensions: namely, a strong belief in and acceptance of organizational objectives, a quest for more effort towards realizing organizational objectives, and a strong need to stay with the organization over time.

In this research, the researcher measured affective commitment using the affective commitment sub-scale of OCQ. This is because the items in this scale recorded reliability with alpha cronbach.74 [27]. There are seven items with five-point response scales ranged from strongly disagree to agree in this sub-scale strongly. The examples of the item are "I do not sense I strongly belong to this company" and "I do not feel emotionally attached to this university".

\section{FINDINGS}

In the course of achieving the objectives of this study, Hypothesis 1 was assessed by testing the direct effect of LMX construct on affective commitment. After that, H1a, H1b. $\mathrm{H} 1 \mathrm{c}$, and $\mathrm{H} 1 \mathrm{~d}$ were measured as well by testing the direct path between LMX dimensions on affective commitment. The results reveal that positive and significant relationships exist between most of these relationships mentioned above. Table 1 shows the finding of direct paths between LMX dimensions on affective commitment.

Table 1: Direct Relationships between LMX dimensions and affective commitment

\begin{tabular}{|l|c|c|c|c|}
\hline Path & $(\boldsymbol{\beta})$ & T Statistics & $\begin{array}{c}\text { Palue } \\
\mathbf{S}\end{array}$ & Result \\
\hline LMX -> AC & 0.441 & 8.218 & 0 & supported \\
\hline AF -> AC & 0.161 & 2.983 & 0.003 & supported \\
\hline LO -> AC & 0.124 & 1.86 & 0.063 & $\begin{array}{c}\text { Not } \\
\text { supported }\end{array}$ \\
\hline CO -> AC & 0.105 & 1.488 & 0.138 & $\begin{array}{c}\text { Not } \\
\text { supported }\end{array}$ \\
\hline PR -> AC & 0.181 & 2.344 & 0.019 & supported \\
\hline
\end{tabular}

Key: $\mathrm{AC}=$ Affective Commitment; $\mathrm{AF}=$ Affect dimension; $\mathrm{AHMS}=$ Advocating High Moral Standards dimension; $\mathrm{AL}=$ Altruism dimension; $\mathrm{CO}=$ Contribution dimension; $\mathrm{CV}=$ Civic Virtue dimension; $\mathrm{LO}=$ Loyalty dimension; $\mathrm{PR}=$ Professional Respect dimension; $\mathrm{RH}=$ Removal of Harm dimension.

Table 1 shows the findings of the direct effects of LMX dimensions on affective commitment. Of the five proposed hypotheses, three are found significantly correlated, and two with no significant relationship. Specifically, the findings show that LMX is significantly correlated with affective commitment $(\beta=0.441, \mathrm{t}=8.218, \mathrm{p}=0)$. The findings further show that affect is significantly correlated with affective commitment $(\beta=0.161, \mathrm{t}=2.983, \mathrm{p}=0.003)$. Thus, the findings indicate that the $\mathrm{H} 1, \mathrm{H} 1 \mathrm{a}$, and $\mathrm{H} 1 \mathrm{~d}$ are supported. Additionally, the findings show that loyalty as a dimension is not significantly correlated with affective commitment ( $\beta=0.124, t=1.86, p=0.063)$. Thus, the findings indicate that H1b is not supported. Similarity, the findings demonstrate contribution as a dimension is not significantly correlated with affective commitment $(\beta=0.105, \mathrm{t}=1.488, \mathrm{p}=0.138)$. Therefore, the findings indicate that $\mathrm{H} 1 \mathrm{c}$ is not supported. However, professional respect as a dimension is significantly correlated with affective commitment $(\beta=0.181, \mathrm{t}=2.344$, $\mathrm{p}=0.019$ ). Thus, the findings indicate that the $\mathrm{H} 1 \mathrm{~d}$ is supported.

\section{DISCUSSION}

The study focused on the effect of affect on affective commitment, of loyalty on affective commitment, of contribution on affective commitment, and of professional respect on affective commitment, all as dimensions of LMX. The study focused on this type of work-related attitudes because affective commitment is considered a significant outcome of LMX. Alshamrani [28] explained that LMX relates to affective commitment positively. The findings of this study reveal that a significant relationship exists between the LMX as a single dimension with affective commitment. Similarly, the result reveals that two LMX dimensions (affect and professional respect) have a significant and positive relationship with affective commitment. These findings are in line with the reports of [9]. The results imply that employees who are interacting with their leaders positively are emotionally attached to their organizations and do not nurse the intention to leave the organisation. Besides, employees become more emotionally attached to their organisation when they perceived the degree to which their leader has built a reputation within and/or outside the organisation of excelling at his or her line of work.

The results of this study also show insignificant relationships between two LMX dimensions (loyalty and contribution) and affective commitment. This finding differs from those of previous studies that reported a positive relationship between affect, contribution, and professional respect with an affective commitment [29]. However, regarding the relationship between LMX-loyalty, LMX-contribution and affective commitment, this study returned an insignificant association. This result might have been influenced by the fact that the Saudi Arabian context is different from other contexts, and most of the respondents adhere to Islamic customs and traditions. Meanwhile, the results presented in this study may not be necessary to be fully replicated in other climes due to the influences of cultural variables.

\section{CONCLUSION}

While researchers have uncovered several antecedents of affective commitment, LMX stands out as an important factor that gives a significant fillip to employees' level of unalloyed commitment to the organisation. This study demonstrates this phenomenon in a sample of 373 administrative employees of Saudi Arabian universities. Thus, KSA HEIs must take cognizance of all proximal and distal predictors of employees' affective commitment, which directly contribute to employees' working behaviors and organizational effectiveness. The stressful nature of administrative duties demands that management of HEIs must pay close attention to what their employees' need. However, researchers should also consider the impact of affective commitment range of workplace outcomes such as job satisfaction, individual work performance, organizational citizenship behavior, and organizational loyalty. Thus, future studies are recommended to extend the study to other government agencies, such as the employees in the ministry of civil services. 


\section{REFERENCES}

1. Northouse, Peter G. Leadership: Theory and Practice, Fourth Edition, Sage Publications,. J Bus Perspect [Internet]. 2007;11(3):395. Available from: http://www.tandfonline.com/doi/abs/10.1080/09669580408667226

2. Uhl-Bien M. Relational Leadership Theory: Exploring the social processes of leadership and organizing. Leadersh Q. 2006;17(6):654-76.

3. Gerstner CR, Day D V. Meta-Analytic review of leader-member exchange theory: Correlates and construct issues. J Appl Psychol [Internet]. 1997;82(6):827-44. Available from: http://doi.apa.org/getdoi.cfm?doi=10.1037/0021-9010.82.6.827

4. Van Breukelen W, Schyns B, le Blanc P. Leader-Member Exchange Theory and Research: Accomplishments and Future Challenges. Leadership. 2006;2(3):295-316.

5. Loi R, Mao Y, Ngo H. Linking Leader-Member Exchange and Employee Work Outcomes: The Mediating Role of Organizational Social and Economic Exchange. Manag Organ Rev [Internet]. 2009;5(03):401-22. Available from: http://www.journals.cambridge.org/abstract_S174087760000396X

6. Morin AJS, Vandenberghe C, Boudrias J, Madore I, Morizot J, Tremblay M. Affective commitment and citizenship behaviors across multiple foci. J Manag Psychol [Internet]. 2011;26(8):716-38. Available

from: http://www.emeraldinsight.com/doi/10.1108/02683941111181798

7. Liao S, Hu D, Chung Y-C, Chen L-W. LMX and employee satisfaction: mediating effect of psychological capital. Leadersh Organ Dev J [Internet]. 2017;38(3):433-49. Available from: http://www.emeraldinsight.com/doi/10.1108/LODJ-12-2015-0275

8. Ali Bhatti G, Islam T, Hassan Mirza H, Hadi Ali F. the Relationships Between Lmx , Job Satisfaction and Turnover Intention. Int ( Lahore ). 2015;27(2):1523-6.

9. Casimir G, Ngee Keith Ng Y, Yuan Wang K, Ooi G. The relationships amongst leader-member exchange, perceived organizational support, affective commitment, and in-role performance. Leadersh Organ Dev J [Internet]. 2014;35(5):366-85. Available from: http://www.emeraldinsight.com/doi/10.1108/LODJ-04-2012-0054

10. Michel JW, Tews MJ. Does Leader-Member Exchange Accentuate the Relationship Between Leader Behaviors and Organizational Citizenship Behaviors? J Leadersh Organ Stud [Internet]. 2016;23(1):13-26. Available from: http://journals.sagepub.com/doi/10.1177/1548051815606429

11. Liden RC, Maslyn JM. Multidimensionafity of Leader-Member Exchange: An Empirical Assessment through Scale Development. J Manage [Internet]. 1998;24(1):43-72. Available from: http://journals.sagepub.com/doi/10.1177/014920639802400105

12. Ibrahim RM, Ghani MA, Amin A. International Review of Management and Marketing Does Leader-Member Exchange Impact on Organizational ... Does Leader-Member Exchange Impact on Organizational Citizenship Behaviour Readiness? Evidence from State Government Agency. 2017;(January).

13. Bhal KT, Ansari MA. Leader-member exchange-subordinate outcomes relationship: role of voice and justice. Leadersh Organ Dev J [Internet]. 2007;28(1):20-35. Available from: http://www.emeraldinsight.com/doi/10.1108/01437730710718227

14. Dienesch RM, Liden RC. Leader-Member Exchange Model of Leadership: A Critique and Further Development. Acad Manag Rev [Internet]. 1986;11(3):618. Available from: http://www.jstor.org/stable/258314 ?origin=crossref

15. Graen G, Uhl-Bien M. Relationship based approach to leadership: development of leader-member exchange [LMX] theory of leadership over 25 years. Leadersh Q. 1995;6(2):219-47.

16. Babič Š. Ethical Leadership and Leader Member Exchange ( LMX) Theory. 2014;(LMX):61-71.

17. Sparrowe RT, Liden RC. Two Routes to Influence: Integrating Leader-Member Exchange and Social Network Perspectives. Adm Sci Q [Internet]. 2005;50(4):505-35. Available from: http://journals.sagepub.com/doi/10.2189/asqu.50.4.505

18. Jing-zhou P, Wen-xia Z. Under dual perspective of work exchange and social exchange. Nankai Bus Rev Int [Internet]. 2011;2(4):402-17. Available from http://www.emeraldinsight.com/doi/10.1108/20408741111178825

19. Meyer JP, Stanley DJ, Herscovitch L, Topolnytsky L. Affective, continuance, and normative commitment to the organization: A meta-analysis of antecedents, correlates, and consequences. J Vocat Behav. 2002;61(1):20-52.

20. Jain AK. Volunteerism, affective commitment and citizenship behavior. J Manag Psychol [Internet]. 2016;31(3):657-71. Available from:

http://www.emeraldinsight.com/doi/10.1108/JMP-02-2014-0042

21. Meyer JP, Herscovitch L. Commitment in the workplace: Toward a general model. Hum Resour Manag Rev. 2001;11(3):299-326.

22. Porter LW, Steers RM, et al. Organizational Commitment, Job-Satisfaction, and Turnover among Psychiatric Technicians. J Appl Psychol. 1974;59(5):603-9.

23. Allen NJ, Meyer JP. The measurement and antecedents of affective, continuance and normative commitment to the organization. J Occup Psychol. 1990;63(1):1-18.

24. McKenna S. Organisational commitment in the small entrepreneurial business in Singapore. Cross Cult Manag An Int J. 2005;12:16-37.

25. O'reilly C, Chatman J. Organizational commitment and psychological attachment: the effects of complience: identification and interorganization on prosocial behavior. J Appl Psychol. 1986;71(3):492-9.

26. Shore L, Tetrick L. A Construct Validity Study of the Survey of Perceived Organizational Support. J Appl Psychol. 1991;76(5):637-43.

27. Kim HK. Work- Life Balance and Employees' Performance: The Mediating Role of Affective Commitment. Glob Bus Manag Res An Int J. 2014;6(1):37-51

28. Alshamrani M. The Relationship between Leader Member Exchange, Job Satisfaction and Affective Commitment, Gender-Similarity Roles in the Segregated Work Environment in the Kingdom of Saudi Arabia (KSA). Int J Bus Manag [Internet]. 2017;12(5):1. Available from: http://www.ccsenet.org/journal/index.php/ijbm/article/view/66360

29. Lee J. Effects of leadership and leader-member exchange on commitment. Leadersh Organ Dev J [Internet]. 2005;26(8):655-72. Available from http://www.emeraldinsight.com/doi/10.1108/01437730510633728

\section{AUTHORS PROFILE}

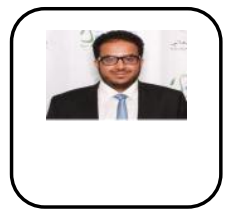

Rajeh Bati Almasradi is a doctoral student with Azman Hashim International Business School, Universiti Teknologi Malaysia.

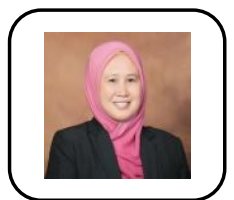

Siti Aisyah Panatik, is an Associate professor with School of Human Resource Development, Faculty of Social Sciences and Humanities, Universti Teknologi Malaysia,

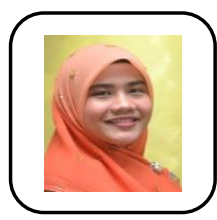

Nurul Farhana Noordin, is a Senior Lecturer with School of Human Resource Development, Faculty of Social Sciences and Humanities, Universti Teknologi Malaysia, 